\title{
Playing with Place in Early Childhood: An analysis of dark emotion and materiality in children's play
}

In this paper we bring together the cultural studies of emotion with theories that foreground the agency of place and objects in order to analyse the entanglement of place, children and emotion (particularly fear) in children's play encounters. When children, objects and places come into play with each other, intensities and emotions emerge. Through an analysis of examples from two ethnographic studies in which play encounters between children and place seem to evoke fear, we explore the potentialities of what is evoked. Fear is bounded in place (Ahmed, 2014) and experienced materially and bodily. As fear becomes entangled in the materiality of place and bodies, emotions work to characterise and categorise bodies (human and non human), in ways that connect to anthropocentric and colonial meta-narratives of animal / human and victim / aggressor. We make the case that the cultural studies of emotion can offer a means through which it is possible to connect the micro and the macro, working at these different scales in order to consider the political implications of re-conceptualising play encounters through new materialism. 


\section{[A] Introduction}

In this paper we bring together the cultural studies of emotion with theories that foreground the agency of places and objects in order to analyse the entanglement of place, children and emotion (particularly fear) in children's play encounters. Children play in and with places, in physical material and discursive contexts. Drawing on new materialist ontologies of early childhood (Lenz Taguchi, 2010) we posit that when this happens, objects and places act on children during play, as children, things and places are "trying to make themselves intelligible to each other" (Lenz Taguchi, 2010: 152). Drawing on Milligan et al's (2005) view that engagements with place are 'emotionally textured' (p. 57), we position emotion as a means of understanding the significance of intra action with place and things (Lenz Taguchi, 2010) within children's play encounters. Emotionally textured meanings circulate within and become attached to places (Milligan et al, 2005) during play encounters between children, places and objects. Focusing specifically on fearful emotions in these terms also allows us to show that 'dark' emotions matter in children's play, because feelings of fear seem to propel certain kinds of play. Further, in recognising that "emotions work to align bodily space with social space" (Ahmed, 2014: 69), fear works to make distinctions between bodies (both human and non-human) 'under threat' and bodies that 'threaten' within children's play. 
Building on the literature from new materialist theories of play (Lenz Taguchi, 2010, Rautio, 2013), in this paper we emphasise the agency of materiality and place in children's play encounters. As Lenz Taguchi (2014), amongst others, points out, new materialist readings of early childhood mark a paradigmatic departure from previous scholarship on children's play. Within social constructivist readings of children's play, it is well documented that play engages with identities within wider social and cultural discourses (Brooker, 2010, Kendrick, 2005, Wohlwend, 2009) and children can explore emotional responses within their play (e.g. Hyson, 2004). In addition, these perspectives show that children often seek out risk and feelings of exhilaration in their play (Aldis, 1975, Sandsetter, 2009). Taking these ideas further, a new materialist approach acknowledges the agency of place and objects within this play. Horton and Kraftl (2006: 73) have described material objects as 'acting back' and Hultman and Lenz Taguchi (2010) have suggested that sand plays with children just as much as children play with sand. This decentring of the human within readings of play practices has significant consequences for what counts as play (Lenz Taguchi, 2014). Exploring the challenges of understanding play within a posthuman paradigm, Holmes and Jones (2014) propose "play has no identity itself, but can only be fleetingly defined according to its specific time-space context" (p.128). Rather than place and objects merely playing a role in children's play, we see place and objects as 'playing back'. Objects and places transform children and produce play (Jones, 2013; MacRae, 2012). Moreover, this play between 
children, objects and places is productive of both intensities and emotional responses. Whilst within a socio-cultural perspective of play, children can be understood to author play experiences that process and produce identities and emotions, a new materialist reading of play understands intensities and emotions as arising through intra actions between human and non human players.

We discuss two examples of place, young children and objects in play in this paper. In the first, a two year old boy is drawn repeatedly to return to a natural history exhibition which he finds "too scary". There seems to be something about this place and these objects in particular that draw the boy back again and again. In the second example, three girls tap into wider socio-material discourses of aggression, subversion and victimisation through enacting and video recording an impromptu play about bullying. In these examples, there is a sense of the children being drawn towards scenarios that seem disturbing or emotionally risky. Place, objects and children's bodies seem to be drawn together, and moments of intensity emerge within these encounters. In these encounters, places, objects and bodies try "to make themselves intelligible to each other" (Lenz Taguchi, 2010: 152), in ways that are particularly significant to interpretations of children's dark emotions during play we offer in this paper. 
In the second part of our analysis, we show that when children play with fear, they engage in the reproduction of anthropocentric and colonial meta-narratives that work to characterise and categorise bodies, places and objects within broader socio-material structures. In our examples, children's play with fearful emotions take place around intersections of animal / human and aggressor / victim. We connect these observations with Ahmed's analysis of fear as creating an effect of "that which I am not" (p. 67). Whilst these discourses exist culturally and linguistically, they are also experienced and enact their power materially and bodily. In making this argument, we seek to highlight the political dimensions of intra-actions between place, children and objects, and the intensities and emotions these can produce. From a new materialist perspective, sociogeo-political understandings of "that which I am not" require a consideration of intra actions between material and discursive agents in more-than-human contexts. We make the case that the cultural studies of emotion can assist in this endeavour, offering a means through which it is possible to connect the micro (brought into focus through the recognition of the role of place and body within childhood studies (Hackett et al, 2015)) with the macro. Working at these different scales is necessary in order to consider the political implications of re-conceptualising play encounters through new materialism.

\section{[B] Developing a Theoretical Frame: Place, Play and Emotion}




\section{[b1] Theorising Place}

This paper takes children's place relations as a point of departure. Our theoretical focus is upon the body being in the wider world, and resonates with children's spatialities approaches, arising from anthropology, geography and social studies of childhood, and sharing an interest in "putting space first" (Soja, 2004: ix) with regards to how children experience the world (Hackett et al, 2015). Some of this work draws on phenomenological theories, with a particular interest in the interconnection between the body and the wider world (Ingold, 2013; Massey, 2005), and the way in which the world in perceived through the body (Christensen, 2003; Pink, 2009). Rasmussen and Smidt (2003) have written about children's deep engagement with the local places near where they live. This deep engagement leads to an embodied kind of knowledge, such as tacit knowing about how to scale a high wall, leading Rasmussen and Simdt to argue "the neighbourhood is in the children" as much as the children are in the neighbourhood. This notion of knowing through the body resonates with Ingold's (2013) description of anthropology as an endeavour in knowing from the inside. Spatial theory takes seriously what happens in between the body and the world. Pink (2009) recommends a focus on emplaced knowledge, which she describes as "an embodied and multisensorial way of knowing that is inextricable from our sensorial and material engagement with the environment (p.35)." 
Within new materialist work on children's intra actions with objects and place (Duhn, Lenz Taguchi, 2010; Taylor et al, 2013), a key theoretical tenant is that agency emerges “in-between different bodies" (Hultman and Lenz Taguchi, 2010: 530), including human and non-human matter. Within early childhood research, scholars have begun to pay more attention to the sand (Hultman and Lenz Taguchi, 2010), the pebbles (Rautio, 2013) and the water (Somerville 2015) that are involved in children's play. Similarly to the children's spatialities literature (Christensen, 2003; Rasmussen and Smidt, 2003), new materialist readings of early childhood emphasise the materiality of the child's body in place, and recognises the body not as a bounded entity but as a zone of contact. Skin is "not the border of our bodies but a territory or region of interference, a 'diffraction' of communicative 'waves' between matters” (Barad, in Lenz Taguchi, 2010: 48). Thus, as Blaise (2016) acknowledges, whilst embodied engagements with the world are human practices "they have been carried out in intimate relationship with the more-than-human." (p. 624).

\section{[b2] Theorising Emotion in Place}

Recent attention has been given to the role of emotion in children's lives (Kraftl and Blazek 2015) and we seek to connect this work to the conceptualisation of place developed above. In distinguishing between emotions and affect, we draw on Massumi's 
distinction between affects as prepersonal, embodied responses to intensities, and emotions as a projection of feelings or affects into the world (Shouse, 2005). For young children in particular, Shouse (2005), drawing on Massumi, argues that emotion and affect are closely connected, and in this paper we mostly refer to emotions, as we are concerned with the ways in which the children in our examples are consciously projecting the intensities of their play encounters, and how these are being read by others.

Emotions locate us in the world (Davidson et al, 2012) and foster our sense of place within social and material interactions (Clarke, 1990). In recognising that emotion, as an embodied phenomenon, "plays a constitutive role in social life” (Crossley, 1998: 17), we posit that emotion is both produced by and produces the self in the world. We draw specifically on Ahmed's (2014) notion of how emotions work to 'stick' bodies together according to past histories of association. Writing specifically about fear, she draws on an encounter between a white child and black man to explore how "fear does become contained in an object" (p.67). Ahmed's analysis draws attention to the ways in which “emotions work to align bodily space with social space" (p. 69), stating that "fear creates the very effect of "that which I am not'" (p. 67). Engaging with fear in this way opens up possibilities to consider children's experiences of playing with place from a range of different scales, connecting the minute details of children's 'in-the-moment' play encounters with place to the political and ideological contexts that bound them. 
As a practice through which feelings and affects can become projected or expressed socially (Shouse, 2005), emotions have become a key site for the socialisation of children in current education practice (Evans, 2015; Gagen, 2015; Gillies, 2011; MacLure et al, 2012; Procter 2013), demonstrative of the ways in which emotion is bound up in constructions of childhood. Within educational studies, scholars critique the idealised child' imagined and reproduced through emotional pedagogy (MacLure et al, 2012). It is increasingly common for children to encounter individualised psycho-therapeutic interventions, such as anger management courses and peer-mediation training, amongst others, intended to support children's emotional wellbeing, and positioned as necessary for academic success and future economic prosperity (Ecclestone, 2013; Ecclestone and Brunila, 2015). Ecclestone (2015) states that formal schooling is propelling emotional pedagogies that aim 'to develop the attributes associated with emotional wellbeing, such as resilience, optimism, emotional literacy, self-esteem, confidence and stoicism' (p.36). MacLure et al (2012) show how this results in classroom feelings being "taught, appraised, and even modified by authoritative adults" as teachers work to mould "children's feelings, sensations and dispositions into a repertoire of discrete emotions" (p.462). 
Many children can find it difficult to be recognised within the confines of acceptable emotion. The shaping of the emotional worlds of children is, therefore, located within a broader context of therapeutic culture where psychological interventions are offered as solutions to societal challenges and highly popularised (Ecclestone 2015). Play based approaches are positioned as a therapeutic means of allowing children to work through emotions (e.g. Bratton and Ray, 2000; Stagnitti and Cooper, 2009), helping children learn to regulate their emotions (Savina, 2014; Zachariou and Whitebread, 2015). Drawing upon Thomas' (2011) argument that the individualisation of emotion "displace[s] an analysis of the constraints of identity and relations of power" (p.7) in children's lives, we seek to explore the social, cultural and material discourses of emotion. These are enacted through play encounters between children, place and objects, in order to interrogate how the expression and meaning of emotion are learned by children within wider structural contexts.

\section{[b3] Theorising fearful emotions in place}

Fear in play encounters can be understood as productive of borders, reproducing distance between certain types of bodies. Children learn to navigate these emplaced emotional landscapes through their embodied encounters with place; they develop tacit knowledges about who/what/where to fear. Ahmed suggests that people fear that which is 
approaching, fear is felt in relation to that which is not quite present. In arguing this, Ahmed shows that affect is not situated within the body itself (such as the black man who was feared by the white child), but instead is produced through the socio-material narratives that circulate about the body (the 'signs' that are ascribed to the figure). In this way, emotions have a 'rippling' effect (Ahmed 2014), they move sideways, connecting bodies together, as well as backwards and forwards, connecting to traces of the past and orientations towards the future. Children's tacit knowing, we suggest, can only be understood within "the broader world from which it emerges" (Kohn, 2013: 57) and, more specifically, insights into the 'affective economies' (Ahmed, 2004a; 2004b; 2014) at work within the spaces in which fieldwork takes place. Kraftl (2013), for example, shows how certain affective practices have a specific meaning and value within sites of alternative education which they wouldn't have elsewhere.

Procter (2013) explores what it means to be named as an 'angry boy', arguing that, with a primary school context, a state of anger is ascribed as an identifying feature of some children and not others, thus connecting these children to each other and reproducing anger as a signifier feature of 'troubled' and 'trouble' children. The signifying feature of these children as 'angry' also renders them unpredictable and influenced how other children experience them as children to be feared. Thus feelings of fear work to structure the relationships between children, as Ahmed states "[fear] brings [bodies] together and 
moves them apart through the shudders that are felt on the skin" (p. 63). Bodies become clustered together through fear, which "stick[s] objects together as signs of threat" (p. 66). Ahmed moves beyond psychological notions that suggest feelings of fear are "an immediate bodily response to an objective danger" (p. 69), which have gained much traction through highly popularised understandings, such as the fight or flight response. The ways in which we characterise and categorise certain bodies as fearful, Ahmed argues, "does not have its origin in the psyche, but is a trace of how ... histories remain alive in the present" (p. 66). In this way, emotional responses, which can be experienced as personally ours, are always structured and mediated within wider socio-material contexts. For Ahmed, fear "works through and on the bodies of those who are transformed into its subjects, as well as its objects" (p. 62). We show how the patterning of emotion in these ways is enacted in children's play, and that place and objects are entangled within such processes.

Because Ahmed argues that "emotions do not reside positively in anybody or anything ... [then] ... 'the subject' is just one nodal point in the economy, rather than its origin and destination" (p. 46 original italics). As 'signs' move with momentum across multiple subjects, then we see an increase in the affective value of the sign. In the case of the 'angry boy', the more that this signifier is utilised across different scales, from popular psychology, policy rhetoric, practitioner talk, peer talk etc., the more that the 'angry boy' 
will be feared by those who learn to characterise themselves against him. Bringing these ideas to children's play allows us to identify the ways in which the patterning of childhood emotion over time is constituted through play encounters between place, children and objects.

\section{[C] Playing with fearful emotions}

We turn now to two case studies in which places, children and objects played together in ways that engaged with notions of emotion, fear and taking risk. The examples are from two separate ethnographic studies, both based in northern England, which prioritised the analysis of movement, embodiment and emotion in children's spatialities. In the first example, a two-year-old boy, Bryan, explores a natural history exhibition, which seems to both fascinate and scare him. Occurring within part of a larger ethnographic study of young children's museum visiting, two-year-old Bryan repeatedly dragged his mother away from the rest of the group to return to this part of the museum. He repeatedly voiced his fear, whilst continuing to re-enter and leave the space. The materiality of the natural history exhibition, including its lighting and collections, seemed to evoke certain kinds of intensities and emotions for Bryan, which moved his body towards, in and out and this space. The second case study draws on an ethnographic study in a junior school (ages seven to eleven) to examine how children's bodies and objects play with social, cultural 
and material discourses of fear as they create impromptu plays with imaginary scenarios between bullies and victims. One extract from an impromptu play created by three girls, Cheryl (victim), Katie (bully) and Ella (camera) is analysed in this paper, in which one of the girls is beaten up by another and the place, children and objects come together to play with what it might be like to feel scared, isolated, unruly and powerful. We present each case study in turn, before discussing some insights emerging from the applications of our theoretical framework to these examples. All names used in the case studies are pseudonyms.

\section{[c1] Case Study 1: Bryan in the natural history exhibition}

The children ran to the natural history gallery, when I caught up with them, Millie and Izzy were spinning round and round on the air vent, laughing. Bryan watched them, then pulled away from the main group, pulling his mum (Clare) with him and heading across the gallery. As we explored, Clare said to me 'I wonder why he always wants to go off by himself'. He kept trying to get her to pick him up, and she said 'I think he is still getting used to the space'. Bryan headed for areas of the gallery that were low lit. First, he pulled Clare towards the tunnel in the tree, he looked 
in, stepped back out, then walked under the tunnel. He lifted each flap and looked in each hole to see what was there. Clare said 'what's that, is that a wiggly worm?' Bryan headed towards a dark enclosed area, pulling Clare along with him. He stepped in, stepped out again, walked inside and looked around. Clare said 'what can you see?' he pointed at the alligator head and said 'dinosaur'. He looked worried and walked back out of the area. He walked back in again and went to look into a glass case. Staring into the case, he commented 'too scary for me'. Clare and Bryan looked together at a turtle and a bee.

Small children's interest in taxidermy in particular comes up frequently in research in children in museum spaces (Kirk, 2013). Bryan made a series of twelve visits to the same museum with his mother and a group of friends, as part of his study, including ten visits to this natural history gallery. This exhibition in particular was lowly lit throughout, and the layout of the space included lots of small enclosed 'rooms within the room' displaying a range of taxidermy, skeletons and models of animals. Some of these displays were of animals that would be dangerous if alive, including an alligator, and a rhino. Others would generally be considered harmless, such as the animals Bryan found under flaps in the above vignette, which included rabbits and moles. However, even these animals were 
displayed in hidden pockets of space, to be discovered or chanced upon by visitors, their glass eyes staring out from their bodies, which are still covered in the real skin and fur of living creatures.

As a participant observer during these visits, I (Hackett) was aware that Bryan's behavior differed noticeably from his friends (two girls and a boy, all two-years-old), who ran ahead of their parents, confident and excited to explore the exhibition. It also differed from how Bryan was in the rest of the museum. I often accompanied Bryan and Clare (his mother) as they explored the gallery, filming on a handheld video camera. This video footage is characterised by the low lighting, and the gradual coming into view of exhibits, as Bryan, Clare and I peered around corners and reticently approaches glass cases filled with taxidermy and skeletons. Bryan moves into and out of the spaces, toying with the intensities he encounters there. The objects and enclosed, low lit spaces seem to "play back' with Bryan, revealing themselves unexpectedly behind flaps and panels, and defying categorisation and labelling, as Bryan looks and wonders what these things are. Whilst Bryan was afraid of these spaces, and stated they are "too scary", he also seemed fascinated; these places and objects drew him back again and again, dragging his mother by the hand. This example starkly illustrates both how spaces can be differently encountered by different people (the other children were not afraid in this exhibition) in 
terms of the way in which emotionally textured meanings emerge or circulate within places.

\section{[c2] Case Study 2: Children, Schooling and Emotion}

Katie is pretending to graffiti a wall. She is simulating holding a can of spray paint in her right hand and pressing the spray nozzle with her forefinger. As she feigns moving the can to paint along the wall she speaks aloud the word "retard", indicating that this is what she is writing. She steps back and looks at her imaginary work and laughs a high-pitched cackle, as if marking how this act symbolises an undermining of authority... Cheryl stumbles into the scene and pretends to fall accidently onto Katie, her hands land on Katie's back and knock her into the table below the wall she was tagging. As Cheryl rights herself she says "anyway what you doing?" She points at the wall and grabs the imaginary spray can from Katie and pulls it close to her chest. Katie rocks forward toward Cheryl as the can is taken from her. Cheryl's body turns away from Katie, as if she is protecting the can. Katie grabs Cheryl round her waist with both her hands, she pulls her round 
to her right in a circle and drops her to the floor (a bit like a move from a sumo wrestler). Cheryl is on the floor, curled on her side. Katie is leaning over her pretending to punch her in the face as she makes the noises "puh puh". Cheryl shields her face with her forearm. "Here", Cheryl gives Katie the imaginary can and then holds her forehead in her hand to soothe her wounds. Katie stands up holding the imaginary can and pretends to spray it just in front of her face. She says "there is nothing in it" and throws it, over arm, away from her and Cheryl.

This vignette is drawn from an ethnographic study that took place in a junior school (for children aged seven to eleven) over an eight-month period. The school was one of the first in England to apply the Social and Emotional Aspects of Learning (SEAL) initiative. The purpose of this research was to engage with children's experiences and perceptions of what it was like to be part of a SEAL school. I (Procter) generated a range of data through fieldwork focused on a class of Year 5 children (aged 9 and 10), including participant observation, semi-structured interviews with staff, and participatory research with a group of nine children, who created dens (small-scale inhabitable spaces made from fabrics and other materials), films, scrapbooks, planned and impromptu plays and presentations. The play encounter detailed above occurred in a small group room without 
any natural light, accessible from a quiet corridor. The door to the room had a glass panel. The room housed a desk with a computer, some chairs and school resources. The girls had asked to occupy this room to record a play and were not in the company of adults. The play was created in-situ and in-the-moment by the girls and recorded over a 15minute period of time.

The play created by three girls (ages 9 and 10), Cheryl, Katie and Ella, explored the theme of bullying. The girls' play reflected a fictional scenario in which one girl was characterised as the bully (Katie), the second the victim (Cheryl) and the third the mother of the victim (Ella). The mother does not feature in the extract of the play used in this article, but Ella was recording the interaction between Katie and Cheryl using a video camera. The play as a whole represented 'bullying' across different sites: the school playground (extract above), the home and online. Katie and Cheryl actively chose to embody a bully and a victim, and experiences of bullying and being bullied. The commonality between this example and Bryan's exploration of the natural history gallery is that fear does not seem to be an emotion that the children seek to avoid. Cheryl and Katie actively seek out these experiences of bullying and being bullied. Emotions and intensities are evoked and displayed through their play with place and objects by drawing on wider cultural discourses, and potentially lived experiences. 


\section{[D] Taking seriously children's felt intensities in place}

A striking feature of both the case studies presented above is the intense pull or draw with

which place, objects and bodies sought out engagement with fearful or disturbing experiences. From a new materialist perspective, we seek to understand the agential role of place, bodies and objects in these play episodes. The more-than-human world shapes possibilities and conditions for children's experiences (Lenz Taguchi, 2010). Movement and the body's sensing in place was central to how emotions came to texture place and shape play. For example, Bryan returned repeatedly to the exhibition, to approach and peer into the glass cases that were "too scary". Katie and Cheryl adopted certain bodily postures in acting out identities of submission and aggression when playing out their bullying narrative.

Fear is bounded in place. Ahmed (2014) states that "there is a relationship to space and mobility at stake in the differential organisation of fear itself" (p. 68). Bodily use of space in Katie and Cheryl's play communicates aggression, fear and vulnerability through its sense of scale. In the children's play, Katie's actions, as dominant and aggressive bully, focus on taking up 'more' space than Cheryl. Firstly, Katie graffiti's the wall, secondly, she contains the body of another child restricting their movement, and finally she throws the empty spray can into 'open' space. In contrast, we can see how fear makes Cheryl's 
body "shrink back from the world" (Ahmed 2014: 69). Cheryl's body physically shrinks in the scene itself, when she is pushed onto the floor by Katie and curls her body to protect her face from the punches thrown by Katie. Katie and Cheryl's actions are inherently spatial, they both operate within and act upon the dynamic production of the material world. Dominant bodies taking up space and vulnerable bodies shrinking within the girls' play mirrors wider world realities observed by feminist theory (Frye, 1983, Kisuule, 2005), disability studies (Slater 2016) and queer theory (Kafer 2013) in which marginalised groups are either forced or self-regulate themselves to take up less space.

Bryan's intra action with the natural history gallery seems to respond to the darkness of the space and the objects found there, such as skeletons and taxidermy of animals. In her discussion of her own exploration of an art exhibition of 'monstrous' taxidermy exhibition, Blaise (2016) describes emotional responses that seem to resonate with Bryan's, including fascination, horror, being drawn back repeatedly to view the exhibit, and drawing closer to try to take on board the reality of what she is looking at. Blaise describes these exhibits as "disorientating and intoxicating" (p.621). Aiming to encounter the objects viscerally, her analysis emphasises the agential nature of the objects themselves, the bodily effects they had on Blaise herself. She writes "These bodies did something. They captivated, they moved, and they intrigued me" (p.624). In response she was "allowing my body to be pulled back into the room, uncertain what might happen" 
(p.624). Similarly, the natural history gallery seemed to draw Bryan back, his words and actions seemed to convey the pull of these objects on his body.

In both cases, place and the bodily experience of place acted on children, producing certain kinds of child and certain kinds of emotion (Lenz Taguchi, 2014). This embodied play between children, place and objects (both 'real' and imagined) referenced emotions that adults would traditionally seek to protect children from; fear, anxiety, threat and violence. They are the kinds of emotions that adults frequently struggle to validate in young children (Sorin, 2003). Yet in both cases, children and places in intra action actively sought to encounter these kinds of intensities and emotions through their play.

\section{[E] Discourses, play and meanings over time}

Clare, Bryan's mother, observed and described Bryan's behavior in the natural history exhibition over the course of visits as different from his behavior in any other context. She was attuned to the way in which he anticipated the natural history gallery during each visit; this anticipation was linked to certain locations on a path the group took through the museum on each visit, on their way towards the natural history exhibition. Ahmed (2014) describes how fear is felt in relation to the approach of bodies or objects. Bryan fears that 
which is nearly present. His fear is located in an unconscious imagining connected to the body or object, as Clare suggests in the following interview;

I think I definitely notice the difference in Bryan as soon as we get - once they first arrive at the museum they're all excited aren't they, Bryan's really excited and wants to go and play with them and run around with the other children. But then as soon as we start to walk around past the cow and into the museum, I think that's when Bryan starts to get a little bit nervous and wants to.... He doesn't then go off with the other kids, he makes sure then he's with me at that point, it's like he knows what's coming, and he makes sure that he's with me from that point, he'll want to be carried or he'll want to.... Cos he does like to be carried quite a lot around the museum which does my head in cos I just can't any more, he's too heavy! But I guess that just might be part of the fear that he knows what's coming and he just wants to make sure I am with him I guess. But it's definitely him deciding where to go and leading us, although I might suggest going somewhere else cos that's where the other kids are. But if he doesn't want to go there, then he won't go. He'll tell me where he wants to go! 
Interview with Clare, Bryan's mother

Bryan remembered both the natural history exhibition and the emotions that it evoked from previous visits. He sought these emotional experiences out on repeated visits, whilst also ensuring his mum was physically close as he got nearer to this spatio-temporal (Massey, 2005) moment. Feelings of fear, it has been suggested, draw us closer to objects of love; "the turning away from the object of fear also involves turning towards the object of love" (Ahmed, 2014: 68 original italics). In this way, "fear allows the subject to get closer to the loved object" (ibid: 68). The object of love (his mother) becomes a 'defense' against the threat of the fearful museum objects and spaces, as Bryan brings his body into close contact with his mother's in this place. During this walk through the museum, memories combined with present material realities create patterns of engagement over time during repeated visits to the museum.

Patterns can also be noted in the girls' bullying play. However, these patterns are not repetitions in the ways described above, but reflective of the ways in which the girls' movements within imagined place are entangled within wider socio-material discourses of bullying. The extract below follows directly from the one in the previous section, and reflects the ways in which characterisations of bully and victim were enacted through the children's movements and gestures. 
Cheryl stands up and says, "Anyway you shouldn't be doing that..." She says this in a high-pitched but quiet voice, becoming quieter towards the end of the sentence. Katie affirmatively states "NO!" and walks past Cheryl flicking her in the face as she speaks. Cheryl brings her hands up to protect her face and her upper body curls inwards as she does so. Katie struts off. Cheryl then threatens Katie, stating that she will tell the teacher. She is holding her hands up to her chest, they are clasped together. Her expression is one of fear, her eyebrows are widened, and she is stood mainly on the spot. Everything about her expression and body posture makes her look vulnerable. Katie has her back to her and then she turns back and walks toward Cheryl. She walks with her back straight and her chest puffed out a little. She pushes Cheryl with her hands. Cheryl uses her arms to shield her torso and twists the front of her body to her right away from Katie. Katie steps back and Cheryl says "OK, OK”. Katie walks away towards the camera. She calls to Cheryl "Weirdo!" and without looking at Cheryl, holds her arm behind her with her palm facing her as she walks away. It's almost signaling to back off or else. 


\begin{abstract}
Cheryl takes a couple of steps forward. Her body hunched forwards and she cries as she pulls one arm round her stomach and her other hand up to her face, with her elbow resting in the opposite hand.
\end{abstract}

In the play, place, the girls, and objects come together to represent the emotional subjectivities of 'bullies' and 'victims'. The bully is personified as rebel who lacks care and consideration for both their environment and other people. Rebellion is represented when Katie makes a material mark on the landscape through the act of graffiti, stirring a fearful response in the second central character, who, as the play develops, becomes 'the victim'. The intra action between the bully, the wall, spray-can and suggested marks that are left behind have a particular culturally situated meaning, especially with the context of a school. The meanings that these two girls attach to the act of graffiti are framed by discourses of disrespect and rebellion, which in this case are enacted materially. The girls reproduce broader material discursive characterisations of 'bully' and 'victim' within the play, portrayed through movements-in-place; the bully is aggressive, defiant and hurtful and the victim is meek, compliant and vulnerable. The ways in which the girls move their bodies and use gesture in the extract above could be considered symbolic of such wider contexts, which work to demarcate bodies in particular ways. In this example, the victim is enacted as innocent and the bully as a threat. The example reflects how encounters in 
which place, children and objects play together can be seen as emotional explorations, which produce connections between self and world. Ahmed (2014) also considers the ways in which 'languages of fear' intensifies the 'affective value' of the threatening body. The girls' play occurred within the context of a school, where anti-bullying rhetoric has particular purchase. The image of the bully is part of a collective consciousness amongst children and adults within a school context, producing distinctions between those who are under threat and those who threaten. The bully is portrayed as less than human; the child's fear of this imagined bully, who could position them as victim, demonstrates how "fear creates the very effect of "that which I am not"" (p. 67). Our analysis reveals the ways in which emotions that work to 'stick' bodies (both human and non-human) together according to past histories of association (Ahmed, 2014) can be reproduced and, potentially, contested through more-than-human play encounters.

\section{[F] Conclusion}

Viewing scenes such as Katie and Cheryl's portrayal of bullying can feel uncomfortable for adults. Bryan's fear in the museum presents a dilemma for the adults bringing him to this space; should we continue or desist? Clare, Bryan's mother, felt quite sure that fear in the gallery was not a negative emotion for Bryan, when she explained 'But if he doesn't want to go there, then he won't go. He'll tell me where he wants to go!'”. Adults may 
ponder and worry about children's fearful emotions in their play, perhaps wondering if young children can 'deal' with such feelings. This paper has shown how productive play encounters between children, place and objects that evoke 'dark' emotions can be. Certain kinds of objects and places can seem to call the body to respond (Blaise, 2016), as in the example of Bryan and the taxidermy exhibits. Emotionally textured meanings can circulate and become attached to certain kinds of places and bodies (Ahmed, 2014). Movement of the body in and through place mediates these kinds of encounters in different ways; including moving through space to return to emotionally significant spaces (Bryan), and using the body to take up space or to shrink (Cheryl and Katie), according to emotionally loaded enactments of love and fear, self and other.

Moving beyond psychological notions of fear as 'fight or flight' from an objectively fearful object, we have shown that the patterning of emotion is always structured and mediated within wider material and discursive contexts. Extending Ahmed's (2014) work on cultural politics of emotions, we show that fear works to align bodies with/in wider socio-spatial relations. As Blaise (2016) points out, natural history collections in museums are part of a wider enlightenment project to classify and order the natural and human world, in an attempt to define the 'special' characteristics of humans, and delineate the ways in which they are set apart from the rest of the animal kingdom (Braidotti, 2013; Finnegan, 2002). Walking through the museum displays, Bryan was invited to survey the 
non-human world categorised and organised for the human gaze. As with Blaise (2016), these objects seemed to exert a power over Bryan, calling him to draw nearer and peer, trying to establish what exactly he was looking at. Bryan's strong emotional reactions can be read as an engagement with these questions of humanity, savagery, life and death. Burman (2012) explores how Western understandings of 'child' and 'adult' are entangled in colonial discourses of 'civilising the uncivilised'. As Cheryl and Katie's play continues, the bully is presented as deceitful and cunning, needing to learn to be friends with her peers in order to become better. The transition from bully to friend signifies the body of the bully as something 'lesser'. The bully comes to be positioned as lacking, their supposed inability to control their emotions connects with notions of the irrational and animalistic. The victim is also at risk of being seen as diminished, she needs to 'speak out' and fight against feelings of vulnerability and weakness. Children at the school are encouraged to 'be brave' and 'speak out' if they are being bullied. The closing scene of the play involves Cheryl reaching out to hug Katie, and Katie reluctantly hugging back. The play ends happily because both of the girls no longer occupy the bodies of bully or victim. Their hug is symbolic of civility.

New materialism calls for a reconceptualisation of play (Holmes and Jones, 2014; Lenz Taguchi, 2014), in which places, children and objects intra act with each other. When children play with place, place and objects 'play back'. As a contribution to this call for 
reconceptualisation, we have illustrated how emotionally textured play between place, children and objects can be understood as nested within a complex tapestry of material discursive forces that reproduce notions of the idealised human. In our examples, the intensities and emotions of the play between places, objects and children reflected how meta-narratives of self and other, of what counts as human and less than human, can have presence within children's lives.

\section{References}

Ahmed S (2014) The cultural politics of emotion. London: Routledge.

Ahmed S (2004a) Collective feelings or, the impressions left by others. Theory, Culture \& Society 21(2): 25-42.

Ahmed S (2004b) Affective economies. Social Text 22(2): 117-139.

Aldis O (1975) Play fighting. New York: Academic Press. 
Blaise M (2016) Fabricated childhoods: uncanny encounters with the more-than-human. Discourse: Studies in the Cultural Politics of Education 37(5): 617-626.

Braidotii R (2013) The Posthuman. Cambridge: Polity Press.

Bratton, S. and Ray, D., 2000. What the research shows about play therapy. International Journal of Play Therapy, 9(1), p.47.

Brooker L (2010) Learning to play, or playing to learn? Children's participation in the cultures of homes and settings. In: Brooker L and Edwards S (eds) Engaging Play. Maidenhead: Open University Press, pp.39-53.

Burman E (2012) Deconstructing neoliberal childhood: Towards a feminist antipsychological approach. Childhood 19 (4): 1-16.

Christensen P (2003) Place, space and knowledge: children in the village and the city. In: Christensen P and O'Brien M (eds) Children in the City. Home, neighbourhood and community. London, Routledge, pp.13-28. 
Clark C (1990) Emotions and micropolitics in everyday life: Some patterns and paradoxes of "place". In: T Kemper (ed) Research agendas in the sociology of emotions, pp.305333.

Crossley N (1998) Emotion and communicative action: Habermass, linguistic philosophy and existentialism. In: G Bendelow and S Williams (eds) Emotions in social life: Critical themes and contemporary issues, pp.16-38.

Davidson J Smith M M and Bondi L (eds) (2012) Emotional geographies. Ashgate Publishing.

Ecclestone K (Ed) (2013) Emotional well-being in policy and practice: interdisciplinary perspectives. London: Routledge.

Ecclestone K (2015) Vulnerability and wellbeing in educational settings: The implications of a therapeutic approach to social justice. In: K Wright and J McLeod Rethinking Youth Wellbeing. Springer Singapore, pp. 35-54. 
Ecclestone K and Brunila K (2015) Governing emotionally-vulnerable subjects:

Mechanisms and consequences in the 'therapisation' of social justice. Pedagogy,

Culture and Society 23 (4): 485-506

Evans R (2015) Emotional pedagogy and the gendering of social and emotional learning, British Journal of Sociology of Education 38(2): 184-202.

Frye M (1983) The Politics of Reality. Essays in feminist theory. Crossing Press.

Gagen E A (2015) Governing emotions: citizenship, neuroscience, and the education of youth. Transactions of the Institute of British Geographers 40(1): 140-152.

Gillies V (2011) Social and emotional pedagogies: critiquing the new orthodoxy of emotion in classroom behaviour management. British Journal of Sociology of Education 32 (2): $185-202$

Hackett A, Procter L, and Seymour J (2015) Children's Spatiliaties: Embodiment, Emotion and Agency. Palgrave 
Horton J and Kraftl P (2006) What else? some more ways of thinking and doing ‘Children's Geographies'. Children's Geographies 4(1): 69-95.

Hultman K and Lenz Taguchi H (2010) Challenging anthropocentric analysis of visual data: a relational materialist methodological approach to educational research. International Journal of Qualitative Studies in Education 23(5): 525-542.

Hyson M (2004) The Emotional Development of Young Children. Building an EmotionCentred Curriculum. New York: Teachers College Press.

Ingold T (2013) Making: Anthropology, archaeology, art and architecture. London: Routledge.

Jones L (2013) Children's encounters with things: Schooling the body. Qualitative Inquiry 19(8): 604-610.

Jones L and Holmes R (2014) Studying play through new research practices. In: L Brooker M Blaise and S Edwards (eds) The SAGE Handbook of Play and Learning in Early Childhood. London: Sage. 
Kafer A (2013) Feminist, queer, crip. Indiana University Press.

Kendrick M (2005) Playing house: A sideways glance at literacy and identity in early childhood. Journal of Early Childhood Literacy 5 (1): 5-28.

Kirk E (2013) Gaining young children's perspectives on natural history collections. Journal of Natural Science Collections (1): 38-43.

Kisuule V (2015) Take up Space. https://www.youtube.com/watch?v=B72 O9D4jNg.

Kohn E (2013) How Forests Think: Toward an Anthropology beyond the Human. University of California Press.

Kraftl P (2013) Geographies of alternative education. Policy Press.

Kraftl P and Blazek M (2015) Mapping and making spaces of childhood. In M Blazek and P Kraftl (eds) Children's Emotions in Policy and Practice. Palgrave Macmillan, pp. 291-307. 
Lenz Taguchi H (2010) Going Beyond the Theory / Practice Divide in Early Childhood Education: Introducing an Intra-active Pedagogy. Routledge.

Lenz Taguchi H (2014) New Materialisms and Play. In L Brooker M Blaise and S Edwards (eds) The SAGE Handbook of Play and Learning in Early Childhood. London: Sage.

MacLure M Jones L Holmes R and MacRae C (2012) Becoming a problem: Behaviour and reputation in the early years classroom. British Educational Research Journal 38(3): $447-471$.

MacRae C (2012) Encounters with a Life (less) Baby Doll: rethinking relations of agency through a collectively lived moment. Contemporary Issues in Early Childhood 13 (2).

Massey D (2005) For Space. London: Sage.

Milligan C Bingley A and Gatrell A (2005) Healing and feeling': The place of emotions in later life. In: Davidson J Smith M M and Bondi L (eds) Emotional geographies. Aldershot: Ashgate Publishing, pp.49-62. 
Pink S (2009) Doing Sensory Ethnography. London: Sage.

Procter L (2013) Emotions, power and schooling: the socialisation of 'angry boys'. Journal of Political Power, 6(3):495-510.

Rasmussen K and Smidt S (2003) Children in the neighbourhood: the neighbourhood in the children. In: P Christensen and M O'Brien (eds) Children in the City. Home, neighbourhood and community. London: Routledge, pp. 82-100.

Rautio P (2013) Children who carry stones in their pockets: on autotelic material practices in everyday life. Children's Geographies 11(4): 394-408.

Savina, E., 2014. Does play promote self-regulation in children? Early Child Development and Care, 184(11), pp.1692-1705.

Shouse E (2005) Feeling, Emotion, Affect, Journal Media Culture, 8(6).

Slater J (2016) Youth and disability: a challenge to Mr Reasonable. Routledge. 
Soja E W (2004) Preface. In: K M Leander and M Sheehy (eds) Spatializing literacy research and practice. New York: Peter Lang Publishing, pp.ix-Xv.

Somerville M (2015) Emergent literacies in 'the land of do anything you want'. In: M Somerville and M Green Children, Place and Sustainability. London: Palgrave.

Sorin R (2003) Validating young children's feelings and experiences of fear. Contemporary Issues in Early Childhood 4(1): 80-89.

Sandseter E B H (2009) Children's expressions of exhilaration and fear in risky play. Contemporary Issues in Early Childhood 10(2): 92-106.

Stagnitti, K. and Cooper, R., 2009. Play as Therapy: Assessment and therapeutic interventions. Jessica Kingsley Publishers.

Taylor A Pacini-Ketchabaw V and Blaise M (2013) Children's relations with the morethan-human world. Contemporary Issues in Early Childhood 13 (2): 81-85.

Wohlwend K (2009) Damsels in Discourse: Girls Consuming and Producing Identity Texts through Disney Princess Play. Reading Research Quarterly 44(1): 57-83. 
Zachariou, A. and Whitebread, D., 2015. Musical play and self-regulation: does musical play allow for the emergence of self-regulatory behaviours?. International Journal of Play, 4(2), 116-135. 